\title{
One Hundred Years of Solitude, Indigenous Myth, and Meaning
}

\author{
Jay Corwin ${ }^{\mathrm{i}}$
}

Since 1968 the mythological content of One Hundred Years of Solitude has been examined from a perspective that is almost exclusively Western. Central, key elements of this novel strongly parallel indigenous Colombian mythologies as well as core elements of the Mayan Popol Vuh. Even the matter of God, which comes to a crux in the novel, has been viewed through the lens of Occidental, Judaeo-Christian texts. Excluding Colombia's pre-history and contemporary demographics, a good number of critics may have misunderstood or misread the underlying meanings implicit in particular themes, myths and rituals in the novel. Disambiguation of the novel's re-creations of authentic Colombian mythologies and rituals may lead to a clearer understanding of the novel's themes and ultimately its meanings, thus clarifying its implicit criticism of the rejection of identity. [Article copies available for a fee from The Transformative Studies Institute. E-mail address: journal@transformativestudies.org Website: http://www.transformativestudies.org (C2013 by The Transformative Studies Institute. All rights reserved.]

KEYWORDS: García Márquez, One Hundred Years of Solitude, Indigenous Myth, Chibcha, Guajiro, Popol Vuh.

Much of the initial critical reception of One Hundred Years of Solitude suggests parallels between the novel and the Old Testament (specifically the Pentateuch, the first five books thereof). It is an obvious source because the myths are widely known to Western readers. However, steadfast adherence to Biblical versions of creation, flight, and destruction in certain later critical interpretations of One Hundred Years of Solitude may have resulted in circuitous or needlessly cryptic

\footnotetext{
${ }^{\mathrm{i}}$ Dr. Jay Corwin is a Senior Lecturer in Spanish at the University of Cape Town in South Africa. He has written extensively on Cien años de soledad and other works by Gabriel García Márquez. His most recent work is centered on the aesthetics of $20^{\text {th }}$ century Latin American fiction. This is his second guest edition of Theory in Action. This article is reprinted with permission from Confluencia. Address correspondence to: Jay Corwin e-mail: jay.corwin@uct.ac.za.
}

1937-0229 (C2013 Transformative Studies Institute 